In cooperation with the Kentucky Division of Water

\title{
Kentucky Public Water-Supply Withdrawals During 1995, 2000, and 2005
}

By Aimee C. Downs and William E. Caldwell

Open-File Report 2007-1209 


\section{U.S. Department of the Interior \\ DIRK KEMPTHORNE, Secretary}

\section{U.S. Geological Survey \\ Mark D. Myers, Director}

U.S. Geological Survey, Reston, Virginia 2007

For product and ordering information:

World Wide Web: http://www.usgs.gov/pubprod

Telephone: 1-888-ASK-USGS

For more information on the USGS - the Federal source for science about the Earth,

its natural and living resources, natural hazards, and the environment:

World Wide Web: http://www.usgs.gov

Telephone: 1-888-ASK-USGS

Suggested citation:

Downs, Aimee C., and Caldwell, William E., 2007, Kentucky public water-supply withdrawals during 1995, 2000, and 2005: U.S. Geological Survey Open-File Report 2007-1209, 16 p.

Any use of trade, product, or firm names is for descriptive purposes only and does not imply endorsement by the U.S. Government.

Although this report is in the public domain, permission must be secured from the individual copyright owners to reproduce any copyrighted material contained within this report. 


\section{Contents}

Abstract

Water Use

U.S. Geological Survey Water-Use Program............................................................................................

Kentucky Water-Use Program ............................................................................................................

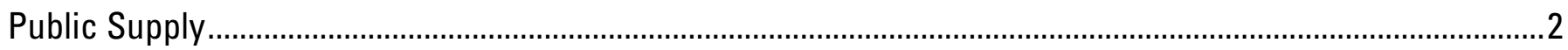

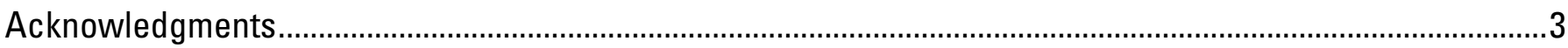

\section{Figures}

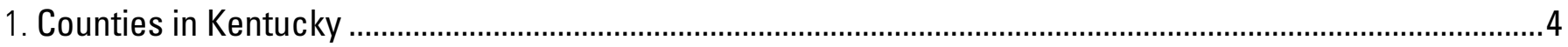

2. Total water withdrawals in Kentucky, 2005 .........................................................................................

3. Total water withdrawals in Kentucky, 2005, without thermoelectric power ...............................................6

4. Permitted public water-supply withdrawal ranges and surface- and ground-water withdrawal totals in

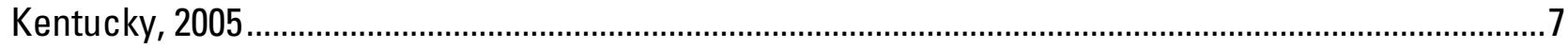

5. Location of permitted public water-supply withdrawals in Kentucky, 2005 ..................................................

6. Average annual permitted public water-supply withdrawals, by watershed, in Kentucky, 2005..................9

7. Percent change in permitted public water-supply withdrawals in Kentucky, 1995-2005 ............................10

8. Total population in Kentucky, 2005 ....................................................................................................11

9. Population increase and decrease plotted against permitted public water-supply withdrawal increase and decrease in Kentucky, 1995-2005......................................................................................

\section{Tables}

1. Permitted public water-supply withdrawals in Kentucky during 1995, 2000, and 2005

\section{Conversion Factors and Abbreviations}

\begin{tabular}{lcl}
\hline \multicolumn{1}{c}{ Multiply } & By & To obtain \\
\hline & Volume & \\
\hline gallon (gal) & 3.785 & liter $(\mathrm{L})$ \\
\hline & Flow rate & \\
\hline million gallons per day $(\mathrm{Mgal} / \mathrm{d})$ & 0.04381 & cubic meter per second $\left(\mathrm{m}^{3} / \mathrm{s}\right)$ \\
\hline
\end{tabular}

\section{Abbreviations}

KDOW - Kentucky Division of Water

KEPPC - Kentucky Environmental and Public Protection Cabinet

NAICS - North American Industry Classification System

NWUIP - National Water-Use Information Program

SIC - Standard Industrial Classification

USGS - U.S. Geological Survey 


\title{
Kentucky Public Water-Supply Withdrawals During 1995, 2000, and 2005
}

\author{
By Aimee C. Downs' and William E. Caldwell
}

\section{Abstract}

The U.S. Geological Survey, in cooperation with the Kentucky Division of Water, has compiled the reported permitted public water-supply-withdrawal data for Kentucky for 2005. Water-withdrawal data for 1995 and 2000 were previously published in Solley and others (1998) ${ }^{3}$ and Hutson and others $(2004)^{4}$, respectively. This report is a graphical representation of permitted withdrawals for 1995, 2000, and 2005.

Public suppliers that are regulated through the Kentucky Division of Water, Water-Withdrawal Permitting Program, withdrew a total of 496, 525, and 558 million gallons per day (Mgal/d) in 1995, 2000, and 2005, respectively. In 2005, $489 \mathrm{Mgal} / \mathrm{d}$ (88 percent) came from surface-water sources, and $69 \mathrm{Mgal} / \mathrm{d}$ (12 percent) came from ground-water sources. Small increases and decreases in permitted public water-supply withdrawals can be attributed to population changes. Large increases and decreases can be attributed to merging of supply systems, change(s) in source, or purchases from other counties.

\section{Water Use}

Water is one of our most valuable resources. The quantity and quality of our water is directly linked to the well-being of our communities, our economy, our environment, and most aspects of our everyday lives. An understanding of how we use this valuable resource is a key component in resolving many issues in the present (2007) and making plans for the future.

\section{U.S. Geological Survey Water-Use Program}

The U.S. Geological Survey (USGS) National Water-Use Information Program (NWUIP) is a cooperative program with State and local governments, which is designed to collect, store, analyze, and disseminate water-use information nationally and locally to a wide variety of government agencies, private organizations and to the public. The program began in 1978 to meet the need for a single source of uniform information on water use and to serve as the focal point for water-use information. The USGS has compiled estimates of water use every 5 years since 1950. Before the NWUIP was started, these estimates were derived from many sources and were based on a variety of methods of data collection and analysis that differed in accuracy. The current (2007) NWUIP compiles data used to

\footnotetext{
${ }^{1}$ U.S. Geological Survey Kentucky Water Science Center, Louisville, Ky.

${ }^{2}$ Kentucky Division of Water, Frankfort, Ky.

${ }^{3}$ Solley, Wayne B., Pierce, Robert R., and Perlman, Howard A., 1998, Estimated use of water in the United States in 1995: U.S. Geological Survey Circular 1200, 71 p.

${ }^{4}$ Hutson, Susan S., Barber, Nancy L., Kenny, Joan F., Linsey, Kristin S., Lumia, Deborah S., and Maupin, Molly A., 2004, Estimated use of water in the United States in 2000, U.S. Geological Survey Circular 1268, accessed June 18, 2007, at http://pubs.er.usgs.gov/usgspubs/cir/cir1268
} 
estimate water use at the State level based on nationally consistent guidelines and procedures and uniform quality assurance for each State.

\section{Kentucky Water-Use Program}

The majority of the data that the USGS reports for the National compilation effort for Kentucky comes from the Kentucky Division of Water's (KDOW) Water-Withdrawal Permitting Program. Water withdrawals in Kentucky are regulated according to laws that were enacted by the Kentucky General Assembly in 1966 (Kentucky Revised Statutes 151.110, 120, 140, 150, 160, 170). These laws defined public waters of Kentucky as all "water occurring in any stream, lake, groundwater, subterranean water or other body of water in the Commonwealth (of Kentucky) which may be applied to any useful and beneficial purpose." Water-withdrawal permits are required for any withdrawal, transfer, or diversion of public water that averages more than 10,000 gal of water per day. Domestic and agricultural uses are exempted by statute as are most thermoelectric-power plants and water injected underground in conjunction with oil and gas operations. While Kentucky does not permit all water withdrawals, 90 percent of all water used in Kentucky is accounted for either by reporting or permitting.

Regulating the withdrawal of public water is administered by the Kentucky Environmental and Public Protection Cabinet (KEPPC) through a permitting program within the KDOW. Under this program and associated regulations (401 Kentucky Administrative Regulation 4:010), water-withdrawal permits are issued only after the KEPPC has determined that water is available for use and that there will be no detrimental effects to the environment or to the rights of other water users. The KDOW administers approximately 700 water-withdrawal permits and requires that records of daily withdrawals be submitted to the KEPPC at the end of each month.

\section{Public Supply}

Public supply refers to water withdrawn by public or private suppliers that furnish water yearround to at least 25 people or have at least 15 connections and are classified with a Standard Industrial Classification (SIC) of 4941 [North American Industry Classification System (NAICS) 22131]. Public suppliers provide water for a variety of uses such as domestic, commercial, industrial, public use, and thermoelectric power. Public use is water provided by a public supplier for firefighting, street washing, municipal buildings, parks, and swimming pools. Public suppliers that are regulated through the KDOW Water-Withdrawal Permitting Program withdrew a total of 496, 525, and $558 \mathrm{Mgal} / \mathrm{d}$ in 1995, 2000, and 2005, respectively.

Public water-supply planning in Kentucky began as a systematic process to address the problem of inadequate potable water sources. The drought of the 1980's created serious and sometimes critical shortages of available drinking-water supplies for many communities in Kentucky. An executive order signed by then-governor Wallace Wilkinson established a task force to study the water-supply issue, which led to the enactment of laws that specifically addressed the need for long-range water-supply planning in the Commonwealth. In the early 1990's, State and local officials began working together by forming County Water-Supply-Planning Councils to develop long-range water-supply plans for each county in the Commonwealth. By July 1999, each of the 120 counties in Kentucky had developed an approved water-supply plan. One important element of these plans was the cooperative planning process between neighboring water suppliers acting as members of the water-supply-planning council. For the first time a county-wide assessment was documented, and proposed service area expansions were delineated so that there were no areas unaccounted for in planning for future public water service.

This cooperative approach to water-supply planning formed the basis for new legislation in 2000: Senate Bill 409 (SB409). This legislation expanded the county-wide planning process to a more regional perspective. Fifteen Area Water-Management-Planning Areas were established, regional 
councils were created from the existing county water-supply-planning councils, and a process was established with the goal of providing access to safe and reliable drinking water to all citizens of the Commonwealth by the year 2020. Funds dispersed through grants and low-interest loans target projects that can provide water to unserved and under-served areas-projects that bring regionalization, consolidation, and mergers of water systems to the modern water-treatment and delivery landscape of the Commonwealth.

\section{Acknowledgments}

The authors acknowledge the contributions of Julia Harrod, Kentucky Division of Water, for the research and retrieval of the public supply data used in this report. 


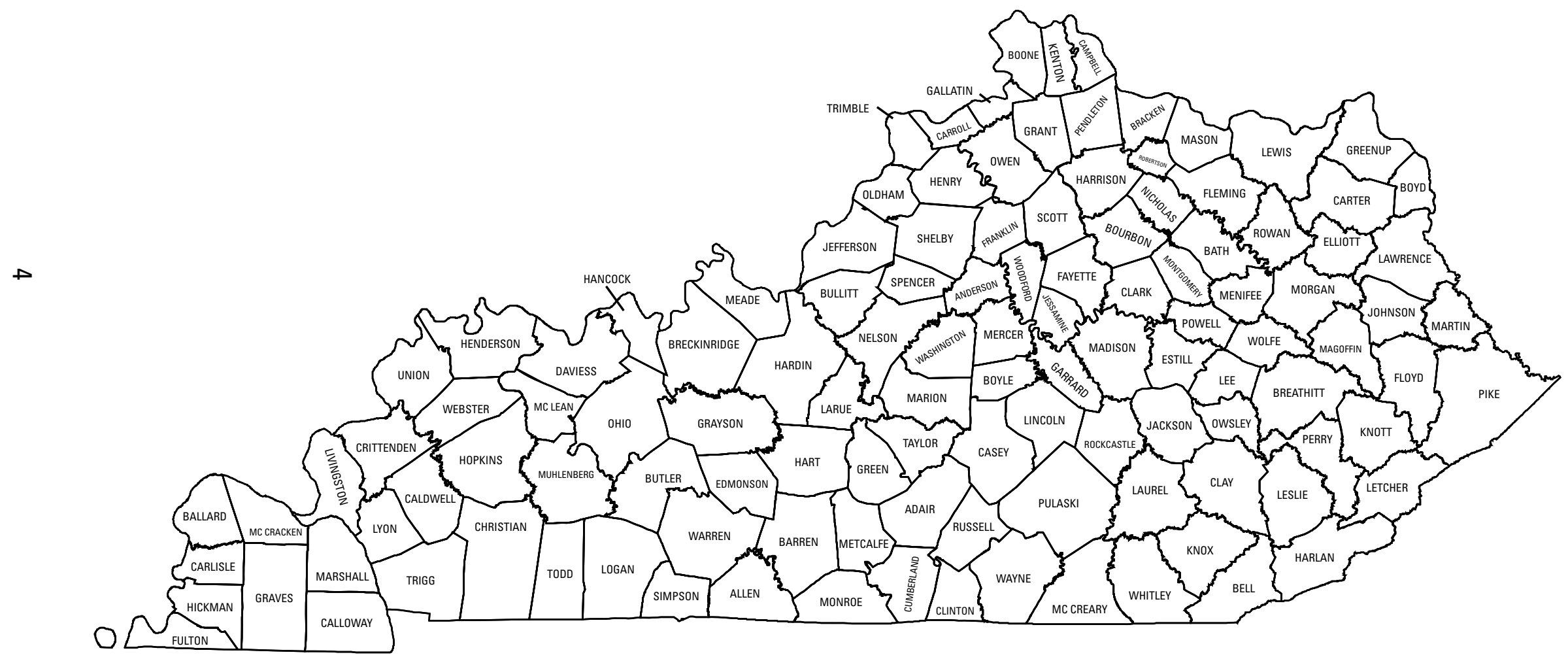

Figure 1. Counties in Kentucky. 


\section{EXPLANATION}

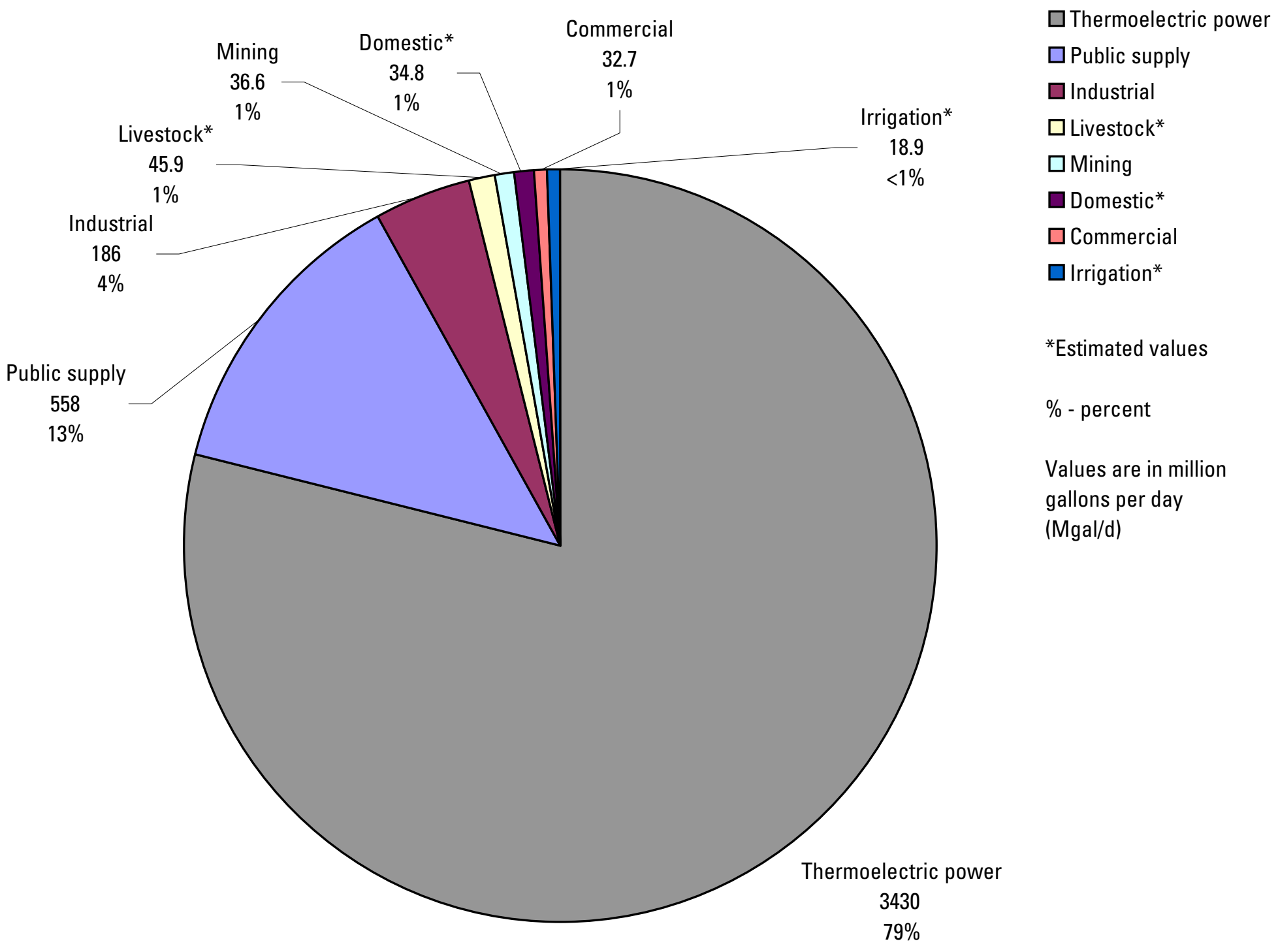

Figure 2. Total water withdrawals in Kentucky, 2005. 


\section{EXPLANATION}

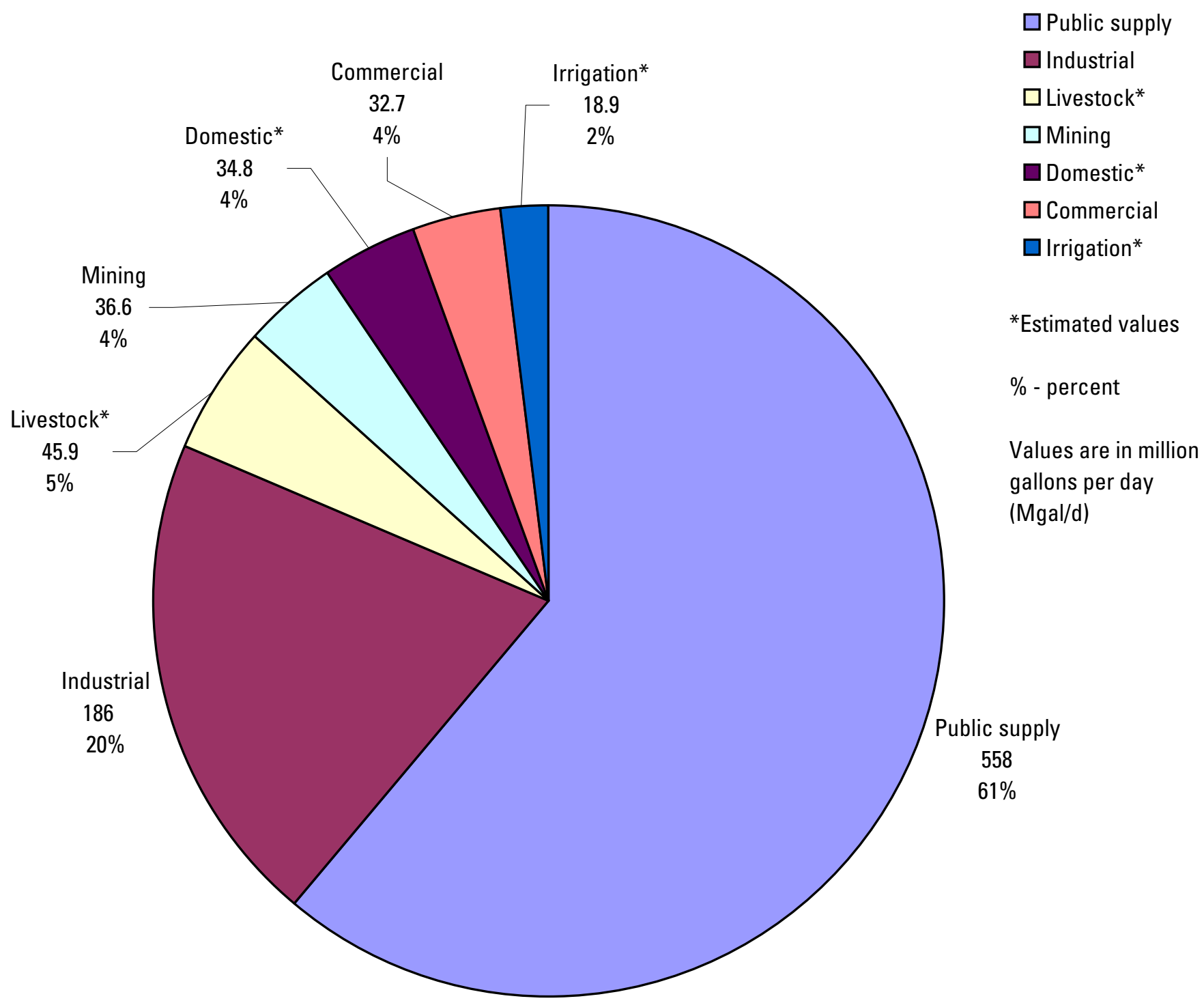

Figure 3. Total water withdrawals in Kentucky, 2005, without thermoelectric power. 


\section{EXPLANATION}

\begin{tabular}{|l|l}
\hline & $0.00-0.10$ \\
$\square$ & $0.11-2.00$ \\
$\square$ & $2.01-10.00$ \\
& $10.01-50.00$ \\
& 140.53
\end{tabular}

0.00 Surface-water withdrawals 0.00 Ground-water withdrawals

Withdrawals are in million gallons per day (Mgal/d)
Of the total permitted public water-supply withdrawals, $489 \mathrm{Mgal} / \mathrm{d}$ (88 percent) came from surface-water sources, and $69 \mathrm{Mgal} / \mathrm{d}$ (12 percent) came from ground-water sources.

Figure 4. Permitted public water-supply withdrawal ranges and surface- and ground-water withdrawal totals in Kentucky, 2005. 


\section{EXPLANATION}

$\triangle$ Surface-water-withdrawal site

○ Ground-water-withdrawal site

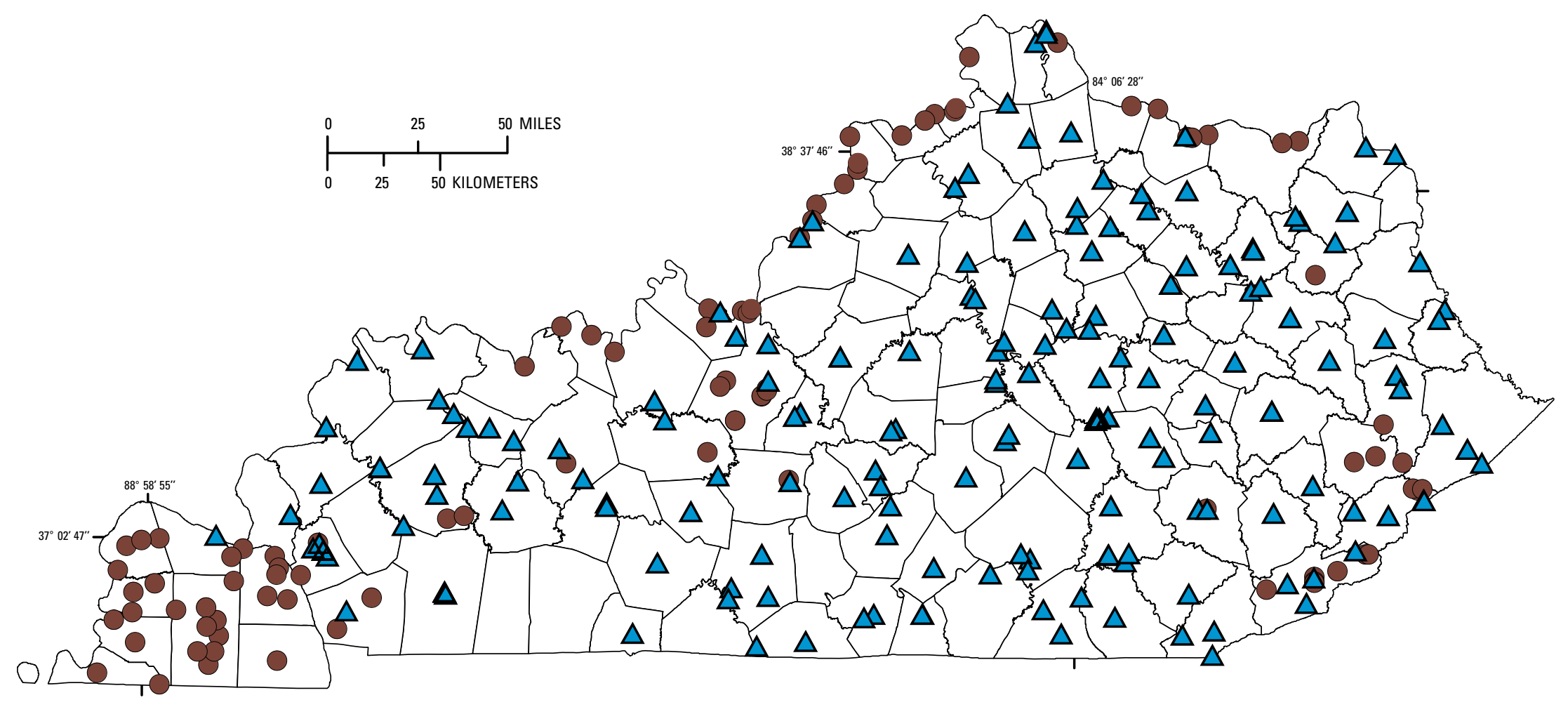

Figure 5. Location of permitted public water-supply withdrawals in Kentucky, 2005. 


\section{EXPLANATION}

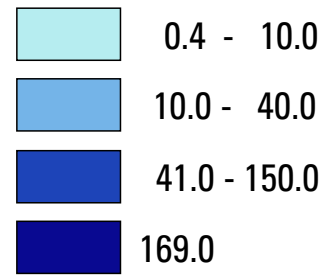

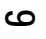

Withdrawals are in million gallons per day (Mgal/d)

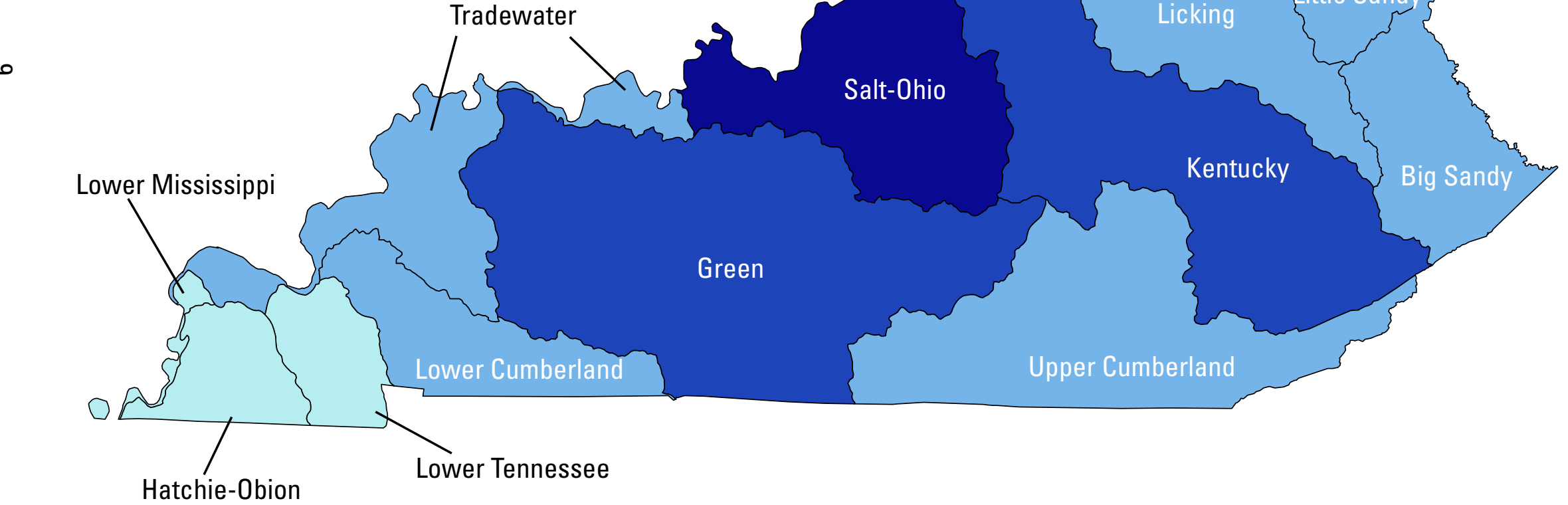

Figure 6. Average annual permitted public water-supply withdrawals, by watershed, in Kentucky, 2005. 
Small increases and decreases in permitted public water-supply withdrawals can be attributed to population changes. Large increases and decreases can be attributed to merging of supply systems, change(s) in source, or purchases from other counties.

\section{EXPLANATION}

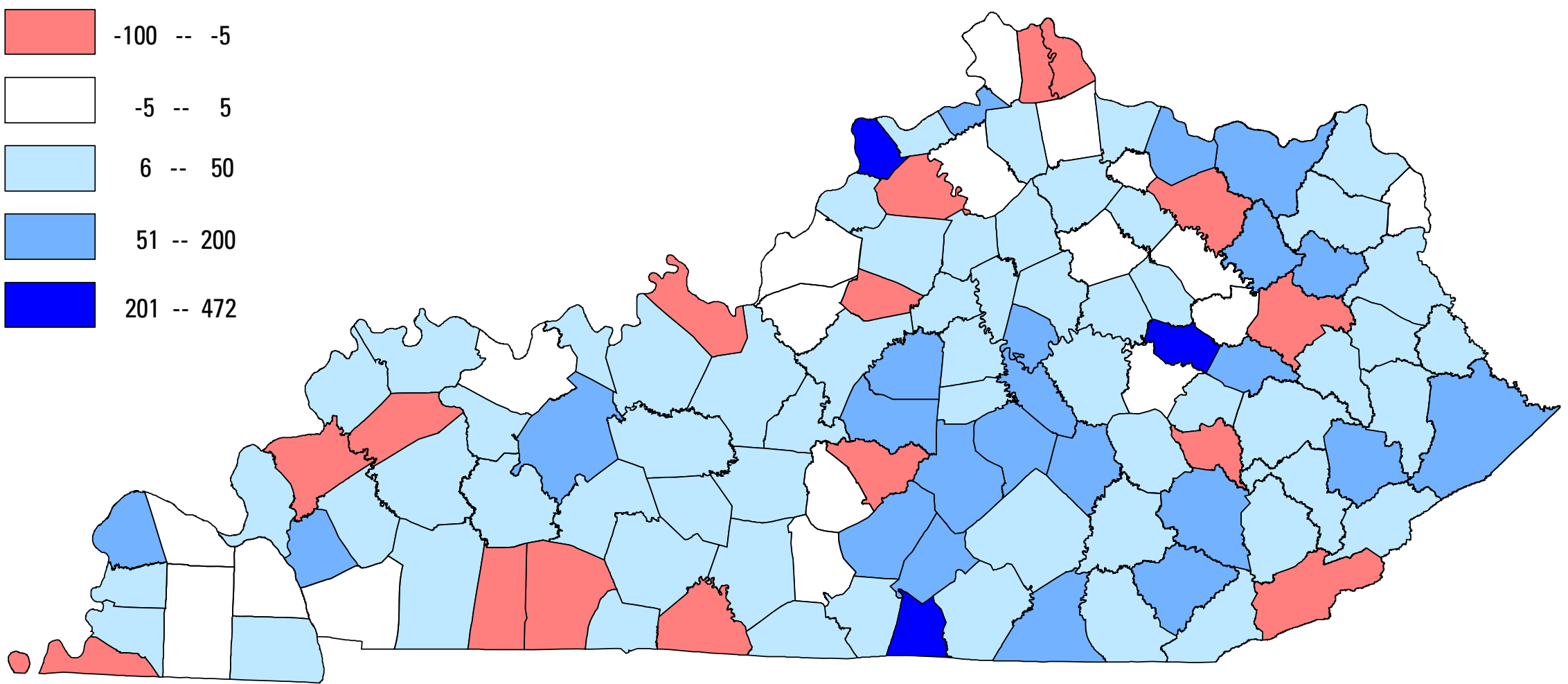

Figure 7. Percent change in permitted public water-supply withdrawals in Kentucky, 1995-2005. 


\section{EXPLANATION}

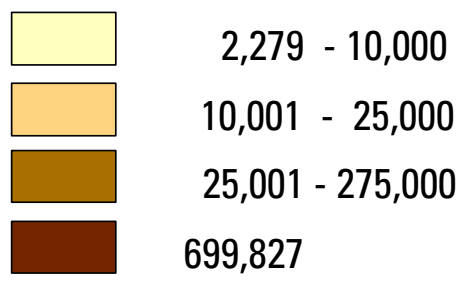

Paducah

- City

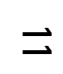

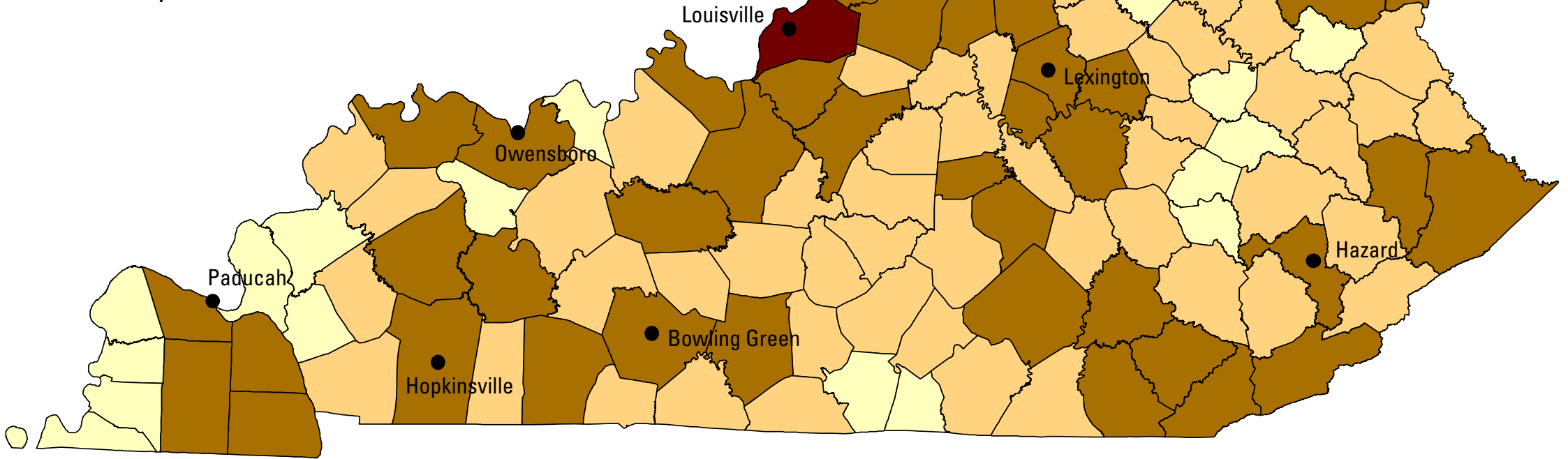

Figure 8. Total population in Kentucky, 2005. 
A rise in population does not necessarily show a corresponding rise in public water-supply withdrawals. Increased water demand may be met by water withdrawn from outside the respective county or outside Kentucky and transferred into the county. Additionally, an increase in public water-supply withdrawals in counties with a decrease in population may reflect the States efforts to provide water to unserved and under-served areas.

\section{EXPLANATION}

Withdrawals

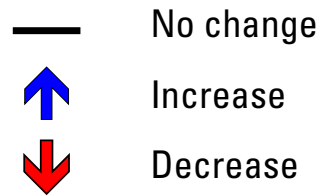

Population

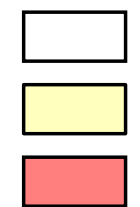

No change Increase Decrease

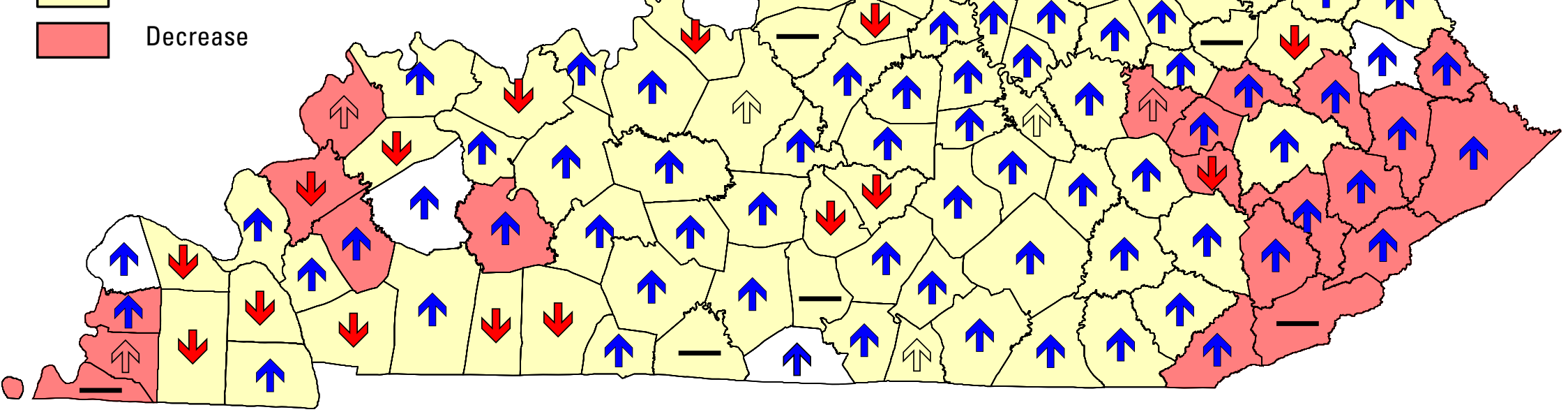

Figure 9. Population increase and decrease plotted against permitted public water-supply withdrawal increase and decrease in Kentucky, 1995-2005. 
Table 1. Permitted public water-supply withdrawals in Kentucky during 1995, 2000, and 2005.

[Values are in million gallons per day (Mgal/d)]

\begin{tabular}{lrrr}
\hline \multicolumn{1}{c}{ County } & $\mathbf{1 9 9 5}$ & $\mathbf{2 0 0 0}$ & $\mathbf{2 0 0 5}$ \\
\hline Adair & 0.92 & 1.26 & 1.71 \\
Allen & 1.23 & .90 & .77 \\
Anderson & 1.64 & 1.70 & 2.17 \\
Ballard & .31 & .58 & .66 \\
Barren & 5.50 & 5.97 & 7.12 \\
Bath & .24 & .22 & .24 \\
Bell & 2.85 & 2.90 & 3.58 \\
Boone & .00 & .02 & .06 \\
Bourbon & 1.55 & 1.46 & 1.60 \\
Boyd & 10.08 & 7.69 & 9.71 \\
Boyle & 4.00 & 4.34 & 5.45 \\
Bracken & .76 & .73 & .99 \\
Breathitt & .61 & .63 & .81 \\
Breckenridge & .88 & 1.02 & 1.11 \\
Bullitt & .00 & .00 & .00 \\
Butler & 1.10 & 1.25 & 1.20 \\
Caldwell & .93 & 1.16 & 1.28 \\
Calloway & 3.07 & 3.31 & 3.43 \\
Campbell & 30.46 & 33.25 & 24.97 \\
Carlisle & .16 & .17 & .21 \\
Carroll & 1.29 & 1.11 & 1.46 \\
Carter & 2.65 & 2.59 & 3.91 \\
Casey & .57 & .66 & 1.02 \\
Christian & 8.50 & 8.22 & 9.58 \\
Clark & 4.70 & 5.64 & 5.47 \\
Clay & 2.25 & 2.66 & 3.92 \\
Clinton & .98 & 1.58 & 3.25 \\
Franklin & 7.36 & 7.94 & 9.27 \\
Grittenden & .48 & .53 & .22 \\
Gallatin & .31 & .68 & .84 \\
Garrard & .94 & 1.37 & 1.56 \\
Grant & 1.58 & 1.87 & 2.17 \\
Faviess & 2.75 & 2.75 & 2.67 \\
Edmonson & 2.37 & 2.78 & 2.83 \\
Elliott & 14.50 & 14.02 & 14.10 \\
Estill & .70 & .82 & .90 \\
\hline & .11 & .14 & .18 \\
Fayette & 40.72 & 44.00 & 48.14 \\
Fleming & .53 & .30 & .19 \\
Grand & 3.22 & 3.85 & 4.30 \\
\hline
\end{tabular}

\begin{tabular}{|c|c|c|c|}
\hline County & 1995 & 2000 & 2005 \\
\hline Green & 0.93 & 1.08 & 0.90 \\
\hline Greenup & 3.46 & 3.18 & 3.73 \\
\hline Hancock & .52 & .63 & .56 \\
\hline Hardin & 11.50 & 9.27 & 12.73 \\
\hline Harlan & 2.85 & 2.88 & 2.66 \\
\hline Harrison & 2.21 & 2.22 & 2.38 \\
\hline Hart & 2.62 & 2.88 & 3.69 \\
\hline Henderson & 7.23 & 8.17 & 10.13 \\
\hline Henry & 1.97 & 1.92 & .00 \\
\hline Hickman & .16 & .17 & .19 \\
\hline Hopkins & 6.93 & 8.53 & 8.59 \\
\hline Jackson & .84 & .92 & 1.04 \\
\hline Jefferson & 140.00 & 139.66 & 140.51 \\
\hline Jessamine & 3.11 & 3.58 & 5.05 \\
\hline Johnson & 1.58 & 2.22 & 2.32 \\
\hline Kenton & 7.75 & 5.19 & 5.88 \\
\hline Knott & .14 & .37 & .36 \\
\hline Knox & .32 & .31 & .49 \\
\hline Larue & .44 & .61 & .59 \\
\hline Laurel & 9.12 & 10.58 & 11.64 \\
\hline Lawrence & .74 & .93 & 1.05 \\
\hline Lee & .60 & .52 & .70 \\
\hline Leslie & .67 & .70 & .85 \\
\hline Letcher & 1.01 & 1.16 & 1.49 \\
\hline Lewis & .67 & 1.02 & 1.32 \\
\hline Lincoln & .93 & 1.53 & 1.72 \\
\hline Livingston & .91 & 1.04 & 1.31 \\
\hline Logan & 2.36 & 2.52 & .00 \\
\hline Lyon & 1.90 & 2.23 & 2.91 \\
\hline McCracken & 7.94 & 7.77 & 7.67 \\
\hline McCreary & 1.02 & 1.20 & 1.85 \\
\hline McLean & .55 & .76 & .75 \\
\hline Madison & 10.56 & 12.33 & 11.86 \\
\hline Magoffin & .58 & .61 & .78 \\
\hline Marion & 1.75 & 3.88 & 4.41 \\
\hline Marshall & 3.46 & 3.61 & 3.39 \\
\hline Martin & 2.72 & 3.25 & 3.41 \\
\hline Mason & 2.71 & 2.99 & 4.58 \\
\hline Meade & 1.92 & .72 & 1.28 \\
\hline Menifee & .00 & .00 & .54 \\
\hline Mercer & 1.94 & 2.72 & 2.58 \\
\hline Metcalfe & .00 & .00 & .00 \\
\hline Monroe & .95 & 1.37 & 1.38 \\
\hline
\end{tabular}

\begin{tabular}{lrrr}
\hline \multicolumn{1}{c}{ County } & $\mathbf{1 9 9 5}$ & $\mathbf{2 0 0 0}$ & $\mathbf{2 0 0 5}$ \\
\hline Montgomery & 1.90 & 2.32 & 2.84 \\
Morgan & .72 & .64 & .00 \\
Muhlenberg & 3.30 & 3.67 & 4.20 \\
Nelson & 3.55 & 4.15 & 5.08 \\
Nicholas & 2.02 & 2.42 & 2.31 \\
Ohio & 2.01 & 2.13 & 4.11 \\
Oldham & 3.58 & 3.94 & 4.17 \\
Owen & 1.44 & 1.51 & 1.42 \\
Owsley & .31 & .31 & .29 \\
Pendleton & .91 & .94 & .93 \\
Perry & 3.33 & 3.56 & 4.15 \\
Pike & 3.83 & 4.32 & 5.77 \\
Powell & .31 & 1.12 & 1.16 \\
Pulaski & 5.60 & 6.54 & 7.53 \\
Robertson & .00 & .00 & .00 \\
Rockcastle & 1.17 & 1.59 & 2.15 \\
Rowan & 3.34 & 5.44 & 6.54 \\
Russell & 2.11 & 2.96 & 3.40 \\
Scott & 1.61 & 1.94 & 2.21 \\
Shelby & 2.95 & 3.16 & 3.13 \\
Simpson & 1.64 & 1.53 & 1.86 \\
Spencer & .48 & .00 & .00 \\
Taylor & 5.36 & 2.64 & 5.00 \\
Todd & .91 & 1.04 & .00 \\
Trigg & 1.84 & 1.88 & 1.81 \\
Trimble & .47 & .60 & 2.69 \\
Union & 2.26 & 2.25 & 3.09 \\
Warren & 14.48 & 17.44 & 15.79 \\
Washington & .95 & 1.02 & 1.63 \\
Wayne & 1.47 & 2.08 & 2.18 \\
Webster & 2.39 & 5.62 & 1.82 \\
Whitley & 1.35 & 1.35 & 1.60 \\
Wolfe & .29 & .36 & .48 \\
Woodford & 2.54 & 2.97 & 3.08 \\
& & &
\end{tabular}

